\title{
Teachers' Participation in Decision Making and Work Performance in Public Secondary Schools in Meru District Council in Arusha Tanzania
}

\author{
Exaudi Peter Macha, Michaela Mhagama
}

\author{
Department of Educational Foundation, St. Augustine University of Tanzania, Mwanza, Tanzania \\ Received: 25 Nov 2021; Received in revised form: 19 Jan 2022; Accepted: 27 Jan 2022 \\ C2022 The Author(s). Published by TheShillonga. This is an open access article under the CC BY license \\ (https://creativecommons.org/licenses/by/4.0/)
}

\begin{abstract}
Teachers' participation in decision-making plays a significant in their work performance. In Tanzania, the idea of participation in decision-making emerged from decentralization policy and was adopted in the field of education through the Education and Training Policy of 1995. The theme was to emphasize that school administrators involve teachers in decision-making to improve school work performance. This study sought to find out the relationship between teachers' participation in decisionmaking and their work performance and identified the factors affecting teachers' participation in decision-making to work performance in secondary schools. Also, the study anchored on Transformational Leadership Theory developed by Mac Gregory Burns in 1978. Moreover, the study adopted a mixed research approach specifically convergent parallel to collate data from teachers, heads of schools, WEOs, and DEO for secondary schools. Validity and reliability of quantitative instruments were tested through content and appearance whereby 0.82 correlation coefficients were obtained to indicate the instruments were valid and reliable. Likewise, the reliability of qualitative tools was obtained through a triangulation system. Quantitative data were analyzed through a computer software program known as SPSS version 20 while qualitative data were analyzed through content analysis methods which involved assigning data into themes, categories, and summarization. The findings demonstrated that there is a relationship between teachers' participation in decision making as it increases efficiency, commitment, accountability and enhances students' performance. Also, the study indicated that teachers' participation in decision-making was affected by inadequate time for participation, financial challenges, facilities, transparency, and lack of leadership training. These factors led to poor academic performance in schools.
\end{abstract}

Keywords-Teachers' participation, decision-making, work performance, public schools.

\section{INTRODUCTION}

In Tanzania, the idea of shared decision-making originated from the decentralization system that began in 1972 when the central government transferred some of its powers and functions to restricted authorities (Godda, 2014). The thought was further adopted in the education sector to enhance rapid development in its activities. Education and Training Policy of 1995 emphasized the transfer of authority from central government to schools and teachers (URT, 2010). The aim was to ensure that education stakeholders are engaged in decision procedures to improve performance in education institutions. In the same vein, Secondary Education Development Program SEDP I and SEDP II stated that the government restated the role of local government to involve lower authorities in school to engage in decision-making process whereby teachers' participation in the implementation of education programs was highly needed (URT, 2010).

Therefore, following the implementation of policy programs, the idea of involvement in decision-making seems to be achieved at higher levels of education administrations than in lower authorities in schools. For example, Education Sector Development Program ESDP 2007/2008- 2016/2017 outlines the structure and process for education sector dialogue in Tanzania mainland from the Ministry level to school level whereby participation of stakeholders of education was given priority to improve performance (URT, 2010). Similarly, the ESDP review of 2016/2017- 2020/2021 emphasized that the existing dialogue structure has played a significant role in fostering collaborations among key education stakeholders to get updates on emerging issues (URT, 2017). 
The Ministry of Education Science and Technology (MoEST) through Curriculum for Secondary Education identified the qualities needed for school heads to have attributes of commitments, dynamism, responsibility and accountability, confidence, and commands of good public relations and pro-team work. School heads with identified attributes understand the importance of teachers' participation in the decision-making process. Therefore, the involvement of teachers in the decision-making required special attention in public secondary schools by infusing leadership skills to the school heads to improve work performance. URT (2010) through the Secondary Education Development Program (SEDP II) stipulates that good governance is the cornerstone in effective utilization of human capacity towards enhancing efficiency and effectiveness in the provision of secondary education. Similarly, URT (2013) in the Curriculum for ordinary level secondary education showed that promoting teamwork enhances work performance.

However; the same document states that school leaders do not have a good relationship with their subordinates in the management of different education matters. This condition lowers teachers' morale, commitment, and work performance resulting in poor academic performance among students. Therefore, school leaders are responsible to ensure teachers are involved in the decision-making process to promote their work performance.

Participation in the decision-making process is a major pillar of work performance in secondary schools. The Ministry of Education Science and Technology in Tanzania through its education programs insist that school administration should involve teachers in the decisionmaking process to improve work performance in secondary schools. Despite the government efforts, some school heads do not abide by the government directives which leads to the poor working performance of teachers in public secondary schools. Also, according to (Ngussa and Gabriel, 2017) report, it showed that there is little teachers' participation in most public secondary schools in Arusha Municipality which leads to low working morale among secondary school teachers. Teachers' participation helps to boost teachers' confidence, ensure effective implementation of curriculum, and reduce teachers' turnover (Owusu, et. al, 2014). In Meru District, the majority of students (70\%) scored division four and other students get zero in their final form four examinations in public secondary schools (NECTA, 2018; 2019; 2020). Therefore, it is in this context the researcher wants to find out the degree of involvement of teachers in the decision-making procedures and how it promotes their work performance in public secondary schools. This study was guided by the following objectives; i. To examine the relationship between teachers' participation in management and work excellence in Secondary education.

ii. To identify factors affecting teachers' participation in decision-making and work performance.

This study is beneficial to many education stakeholders such as policymakers, heads of schools, teachers, and researchers. Policymakers can create effective education policies with clear guidelines on how teachers can participate in decision-making to improve job performance. Also, school heads can easily capture new ideas from teachers once involved in decision-making for school efficiency. Similarly, teachers can be motivated and increase their commitment and accountability in work to raise students' academic performance. Also, this study provides a way forward and encourages more research in schools to seek the best ways to improve teachers' commitment and enhance students' performance in public secondary schools.

\section{LITERATURE REVIEW}

In this section, the researcher reviewed several articles from scholarly works based on the objectives of the study. From the articles, the researcher identified some gaps which call for the interest of the current investigation.

\section{Relationship of Teacher's Participation in Decision Making and Work Performance}

Teachers' involvement in decision-making is vital towards school efficiency. In Iran Sagvandy (2015) investigated teachers' participation in different levels of decision making in the Dezfoul council on developing professional skills. The researcher adopted quantitative methods in the collection of data in a sample size of 70 participants. Also, the researcher used questionnaires and an observation checklist to collect data from the participants. The study identified that there is a positive significant relationship between teacher participation in educational research, administrative, organization, and conference-related decisions. The researcher also added that involving teachers in decision-making helps to increase their productivity to the benefit of students.

Also, (Eris, Kayhan, Bastas \& Gamar, 2017) carried out a study on teachers' and administrative staff views on teacher participation in the decision-making process in Cyprus. The investigation was purely quantitative research. The guiding questions were employed by the researcher to gather data from the participants. The findings indicated that school administrators adopt more democratic attitudes in the decision-making process and include school staff more frequently in the decision-making process in areas of school 
responsibilities and authority to subordinates. In Turkey (Ozan, Ozdemir, and Yirci, 2017) made an investigation on Ethical leadership behaviors of school administrators from teachers' point of view. The researcher used quantitative methods in collecting and analyzing data. The researcher also used questionnaires as the instruments of data collection from the field. The researcher identified establishments of ethical codes for school administrators to help them to decide with integrity, fairness, and in a more ethical manner about teachers' issues. Therefore, the school principal must involve teachers in the planning and establishment of ethical codes for integrity. Similarly, Haryanto (2020) in Nigeria, found that there is a significant relationship between teachers' involvement in academic planning and job performance in secondary schools in Kwara state. Thus, involving educators in the decisionmaking processes in secondary education impacted motivation to the teachers and achieve higher in public secondary schools.

Also, In Ghana Okuoko \& Dwumah (2012) examined employee involvement in decision making and workers performing decision-making was a mixed research workers' questionnaires and interview to collect data from the field. The researcher found out that involvement in decisionmaking impacted positively on workers' commitment and performance in an organization. Therefore, involving teachers in decision-making promotes accountability and commitments of teachers in their job operation in secondary schools. Notwithstanding, Surkino and Siegthai (2010) in seeking whether participative decision-making affects lecturers' performance in higher education in Thailand maintained that involving lecturers in decision making is used to improve not only performance but also organization performance. Although the study was carried out in higher learning educational institutions, it is also applicable in public secondary schools. Teachers' involvement is vital towards school efficiency in schools.

In Nigeria, Olurunsola and Olayemi (2011) conducted a study on teachers' participation in decision-making in secondary schools in Ekit State. The researcher employed quantitative methods in the collection and analysis of data. A teacher decision-making questionnaire (TDMQ) was used to collect data from the participants. The researcher also used the descriptive analysis method to analyze data. The researcher found that participation of teachers in decision-making in the administrative activities enhances teachers to gain experience, removes boredom, frustration and increases workers' commitment, efficiency, and job satisfaction. Also, Tchapchapchet, Iwu, and Ille (2014) in South African University on examining employee participation and productivity found that employee participation in decision making has a positive impact on the effectiveness, efficiency, and productivity of faculty. The involvement of teachers in the decision-making process makes teachers feel they are part and parcel of the institution. Thus, school administrators need to ensure teachers are involved in planning and other school matters to enhance accountability and voluntary participation in the implementation to improve work performance in public secondary schools.

In addition to the foregoing, in Ethiopia Atsebeha (2016) carried out a study on principals' leadership styles and their effects on teachers' performance in the Tigray Region. The researcher adopted mixed research methods in the collection and analysis of data. Furthermore, questionnaires and focus group interviews were used as the instruments of data collection in the field. The study revealed that leadership style has a significant relationship with the job performance of teachers in schools. Therefore, the participation of teachers in the decision-making process in school-related matters is highly dependent on a type of leadership style employed in the school. Some school heads do not see the necessity of involving their employees in the decisionmaking process which leads to the failure of implementation of various school programs. Transformational leadership style is very important in school organization to ensure each individual is motivated to perform duties in school and thus high performance.

Similarly, in Zimbabwe Wadesango (2012) in investigating the influence of teacher participation in decision making on their occupational morale found that participatory decisionmaking leads to more effective organization and higher staff morale. Therefore, employee involvement in decisionmaking promotes motivation and encourages a higher level of accountability and commitment for the school to succeed and hence good job performance.

Likewise, (Kariuki, 2018) in Kenya found that school principals involve teachers in pedagogical ways of teaching and learning, symposium, and staff discussion to improve their job performance. Teachers' participation in decisionmaking in various aspects is vital to school organizations. Involvement encourages new ideas and innovation towards the implementation of the program and hence yields high performance of teachers.

In Tanzania, Ngussa (2017) examined participation in decision-making on teachers' commitment in Arusha Municipality. The researcher used quantitative methods to collect and analyze data from the field. Also, the researcher used a descriptive comparative design to examine the level of participation between private and public secondary schools in Arusha. The decision-making questionnaire method was applied to get data from the participants. The findings indicated that there is a significant relationship 
between teachers' participation in decision-making and teachers' commitment.

\section{Factors Affect Teacher's Participation in Decision Making}

Heads of the school play a significant role in enhancing teacher participation to improve work performance in schools. Despite their roles, some factors determined teachers' involvement in every aspect of decision-making in school.

In Sweden, Paulsrud and Wermke (2019) conducted a study on decision-making in the context of Swedish and Finnish teachers' perceptions of autonomy. The researcher employed mixed research methods in the collection and analysis of data. Moreover, questionnaires and interviews were used as the instruments of data collection in the field. The study revealed that teachers' involvement in management is affected by teachers' education, professional ethics, and institutional norms. Thus, teachers' participation depends on the teachers' level of education, school culture, and the nature of the school administrator. Another related study was carried out by Hammad (2017) in Egypt on decision-making domains and teachers' participation. The study was a qualitative study using a descriptive survey design. The researcher maintained that teachers regarded school decisions as insignificant and irrelevant to their concerns and therefore significant decisions are retained by central administrators. Sometimes the perception of teachers regarding decision-making in school is affected by teachers whereby the decision-making process is left to the key administrators in school and hence implementation became difficult. Therefore, there is a need to train school principals as well as teachers to strengthen their knowledge on the importance of collective decisions to improve work performance in schools.

Also, Saleem, Aslam, Yin, and Rao (2020) investigated principal leadership styles and teacher job performance in China. The researcher used quantitative methods in the collection and analysis of data. Questionnaires were used as the instruments of data collection in the field. The study showed that school principals prefer a directive leadership style to participative leadership. The researcher also, added that principals need to be trained on the useful practice of participative leadership function to be productive. In addition, Mohammed (2017) in Ethiopia unveiled that teachers' involvement in decision-making is affected by lack of transparency, lack of skills in teachers, and knowledge in the decision. Also, the study showed that principals do not have self-confidence and hence interference of political authority affects their decisionmaking. Therefore, teachers in school should be trained to develop their confidence in the decision-making process to improve job performance in secondary schools.

Meintjes (2018) investigated participatory decision-making in schools in South Africa. The study adopted mixed research methods in the collection and analysis of data. Also, the researcher used questionnaires and interview to collect data from the participants. The study revealed that the absence of confident teachers, dialogical teachers' voices in staffrooms and staff meetings, and lack of collegiality in staff relationship affects educator partaking in school decisions. The researcher added that in a school where a hierarchical, autocratic culture exists, principals do not engage, in participatory practices and suffer from accountability pressure alone, struggling to extend decision making within the school management team and excluding the general teaching staff beyond the senior managers. Thus, the autocratic style of leadership in public secondary schools affects the performance of teachers and leads to ineffective implementations of school plans.

Likewise, Kiumi, Chemnjor, and Macharia (2014) conducted a study on determinants of teachers' involvement in the decision-making process by secondary school principals in the Nyahururu sub-count in Kenya. The study used quantitative methods in collecting and analyzing data from the field. Questionnaires were used as instruments of data collection from the participants. The researcher identified that autocratic leadership behavior may nature an exclusive decision-making pattern and also principals do not have human relation skills and consensus-building skills in the decision-making facet of school management. Therefore, school principals need to adopt human relations and consensus-building skills to create a sense of participation in decision-making among teachers in schools to enhance the performance of teachers.

Also, Mugambi (2015) investigated the contributions of heads of schools in supporting and advancing academic excellence in secondary Education in the Tigania west subcount in Meru count in Kenya. The researcher used quantitative methods to collect and analyze data in a descriptive survey design. The study used questionnaires to get data from the participants. The study found that most principals involved their deputies and teachers in decision making, and the school faced challenges such as inadequately trained teachers, teaching and learning materials, science laboratories and libraries affected teachers' involvement in decision making. Therefore, inadequate facilities lead school heads to apply an autocratic leadership style in decision-making. This is because they cannot meet the desires of their teachers hence, low performance. 
Similarly, in Tanzania, Mndeme (2014) made an investigation on the management of teachers' motivation in Temeke Municipality. The researcher used quantitative and qualitative methods to collect and analyze data in a survey research design. Furthermore, the study employed questionnaires, observation schedules, and document reviews to get data from the field. The findings indicated that poor management and planning system, corruption and delay in information and documents to reach the targeted persons, lack of teacher's participation in decision making on different matters affected the performance of teachers.

In the same vein, Mbope (2015) made an investigation on the impacts of teachers' motivation on the improvement of the quality of teaching and learning in public primary schools in Ilala District in Tanzania. The researcher identified that lack of recognition of teachers' work, lack of involvement in decision making, lack of appreciation from education officers and school heads, and poor working conditions affect teachers' participation in decision making. However, this study was carried out in public primary schools, it can is also applicable in public secondary schools in Tanzania. Thus, some education administrators do not value the contribution of teachers in school to make programs effective. School principals should be trained on the importance of group participation to enhance work performance as well as to make effective implementation of school programs.

\section{RESEARCH METHODOLOGY}

This is mixed research whereby the researcher used both quantitative and qualitative methods to get data from the field. Also, for understanding

deeper on the problem, the study adopted a mixed research design specifically convergent parallel. Research design is a specific procedure involved in the research process from data collection process, data analysis, and report writing (Creswell (2012:20). The researcher employed a mixed research design specifically convergent parallel design to collect and analyze data from the field. Convergent parallel mixed methods design is a type of design in which qualitative and quantitative data are collected concurrently, analyzed separately, and then merged at the end of the study (Creswell, 2014). Moreover, the study employed 147 participants from students, heads of schools, WEOs, and DEO for secondary schools. These participants were obtained through Yamane's formula for calculating the sample size. Before the process of data collection, the validity and reliability of the instruments were tested through a split-half system and

0.82 correlation coefficient. This showed that the instruments were valid and reliable. Notwithstanding, after the data collection process, analysis was done with the aid of computer software known as SPSS for quantitative data while qualitative data were assigned into categories, themes, summarization, and integration for interpretation. Finally, the researcher observed the ethical procedures, norms, and regulations for conducting education research such as seeking informed consent, permission, privacy, the safety of the participants, and acknowledging sources of data to avoid plagiarism.

\section{Findings of the Study}

In the presentation and discussion of the findings, the researcher organized the findings based on the research objectives.

\section{Relationship of Teacher's involvement in Decision Making and work Performance}

This objective sought to unveil the relationship between teachers' participation in decision-making and their work performance in public secondary schools in the Meru District council. Participants involved were teachers, Heads of schools, Ward Education Officers (WEOs), and the District Education Officer for secondary schools in Meru District council. Teachers were given questionnaires to fill in while heads of school, WEOs, and DEO were interviewed.

Participants from teachers were asked whether it is important to involve teachers in the decision-making process in public secondary schools. The findings showed that 83.1 percent replied "Yes"it is important while 16.9 percent indicated "No" which means it is not important. The findings are represented in figure 4.1 


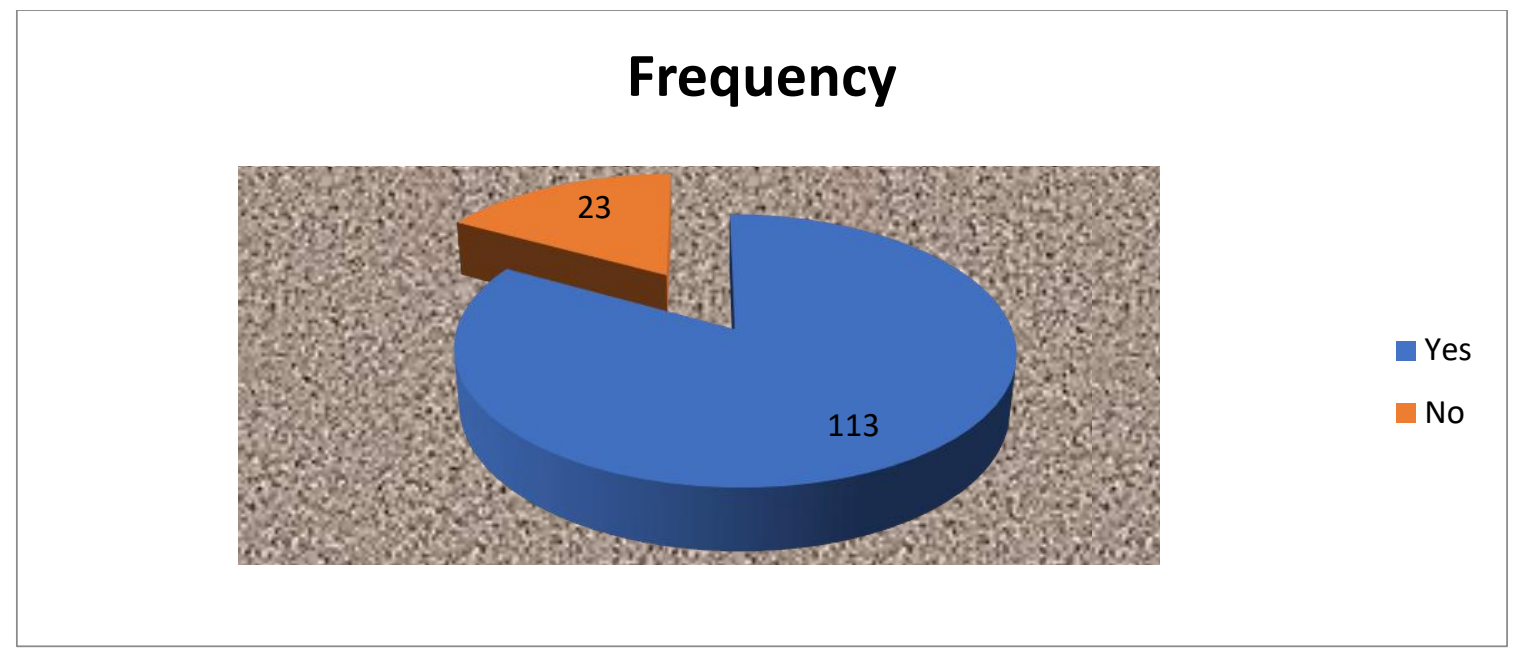

Fig.4.1 Teacher's response on importance of Teacher Participation in Decision-Making

Source: Field Data August 2021

The findings indicated that teachers viewed their participation in decision-making as an important aspect to enhance work performance in secondary schools, however; in some circumstances 16.9 percent neglected because they were not involved in all school-related matters. Some school heads do not involve teachers in all school matters to secure their interest. During the interview, an interviewee reported that:

It cannot be denied that engaging educators in the decision procedures have an optimistic influence on their job performance, but some school leaders have either poor managerial skills or inability to involve their subordinates in some matters due to personal interests. (Interviewee three, 2021)
The result also showed that involving teachers in the decision-making process in all school matters increases their work morale and commitment and hence school goals can be achieved easily. The findings concurred with (Haryanto, 2020) in Nigeria who found that there is a significant relationship between teachers' involvement in academic planning and job performance in secondary schools. Thus, school heads should plan effective strategies to ensure teachers are involved fully in various education and schoolrelated matters to boost their work performance.

Moreover, participants were asked if teachers' participation in decision-making can promote work performance in secondary schools. The data showed that the majority of the participants 89.0 percent accepted while 11.0 percent rejected as represented in figure 4.1

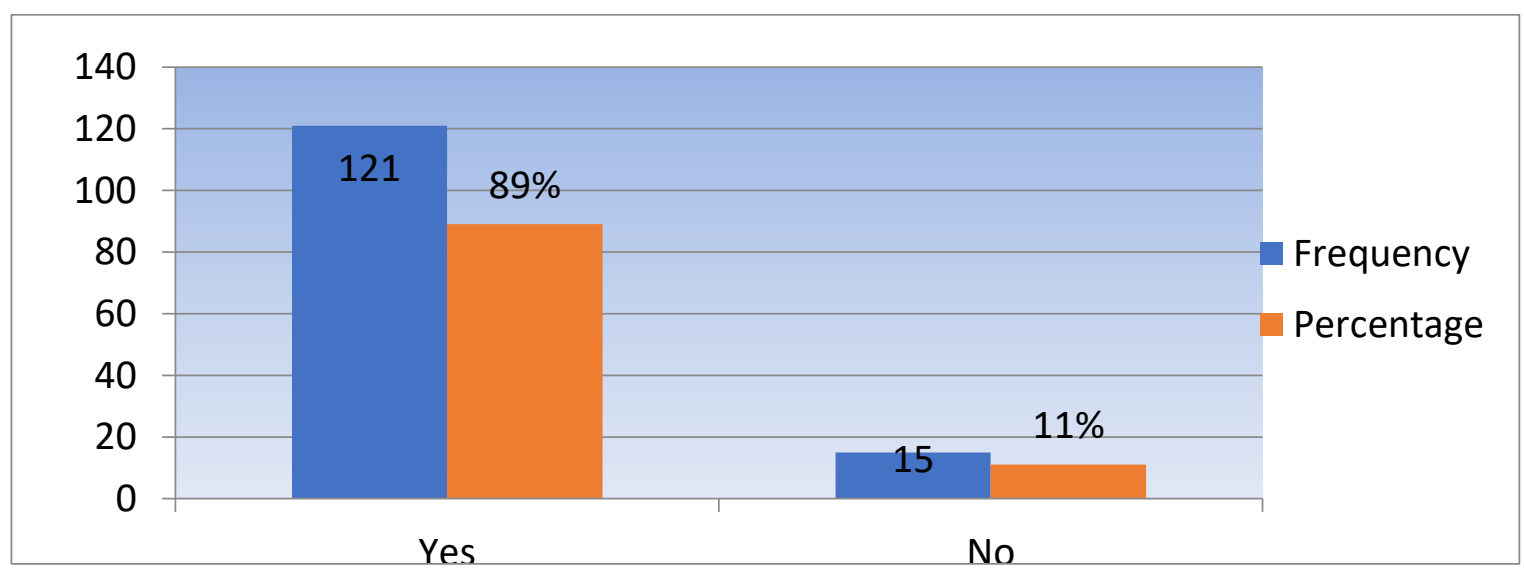

Fig.4.2 Participation in Decision Making Promotes Work Performance

\section{Source; Field Data, August 2021}

The findings demonstrated that involving teachers in decision-making plays a significant on work performance.
Participants viewed the aspect of involvement as a key to making teachers comfortable in giving out their ideas as 
input towards school success. This was also supported by one of the interviewees who said that:

Involving teachers in decision-making in
secondary schools help to make teachers
comfortable in giving out their views to
improve the academic performance of the
students. It promotes the sense of
ownership, understanding the decision
and hence implementation becomes easy
(Interviewee One, August 2021).

The findings also related to the conceptual framework in figure 1.1 which indicated that participation in decisionmaking increases accountability and commitment of teachers and finally high academic performance in students. Moreover, it concurred with the Transformational Leadership Theory which insisted that transformational leaders employ their abilities to promote ideas of others to transfer individuals to higher performance (Moradi and Shabbaz, 2016).

On other hand, 11.0 percent rejected that teachers' participation in decision-making can promote job performance due to the reason that some leaders do not make it applicable in their organization. They thought that it consumes time and therefore dictatorial style is most applicable. However, they may achieve performance, it may result in teachers' turnover, and organization performance may not last long. Another interviewee said:

Inadequate participation of teachers in
the decision-making process demoralizes
teachers in doing their jobs. Most of the
time, they lose morality in performing
their duties. This situation made students
perform poorly in their final
examinations (Interviewee Six August
2021).

Thus, school managers and education administrators in the Meru district should ensure effective teacher participation in decision-making to boost the performance of teachers to achieve higher in academics in long run.

\section{Importance of Teachers' Involvement in Decision- Making}

Also, to understand well the association between teachers' involvement in decision-making and work performance, participants were asked to explain the importance of involving teachers in the decision-making process in secondary schools. The data showed that involving teachers in decision-making helped to create new ideas, enhance academic performance, the solution to challenges, increase efficiency, increase teachers' commitment and reduce conflict in school as represented in figure 4.3.

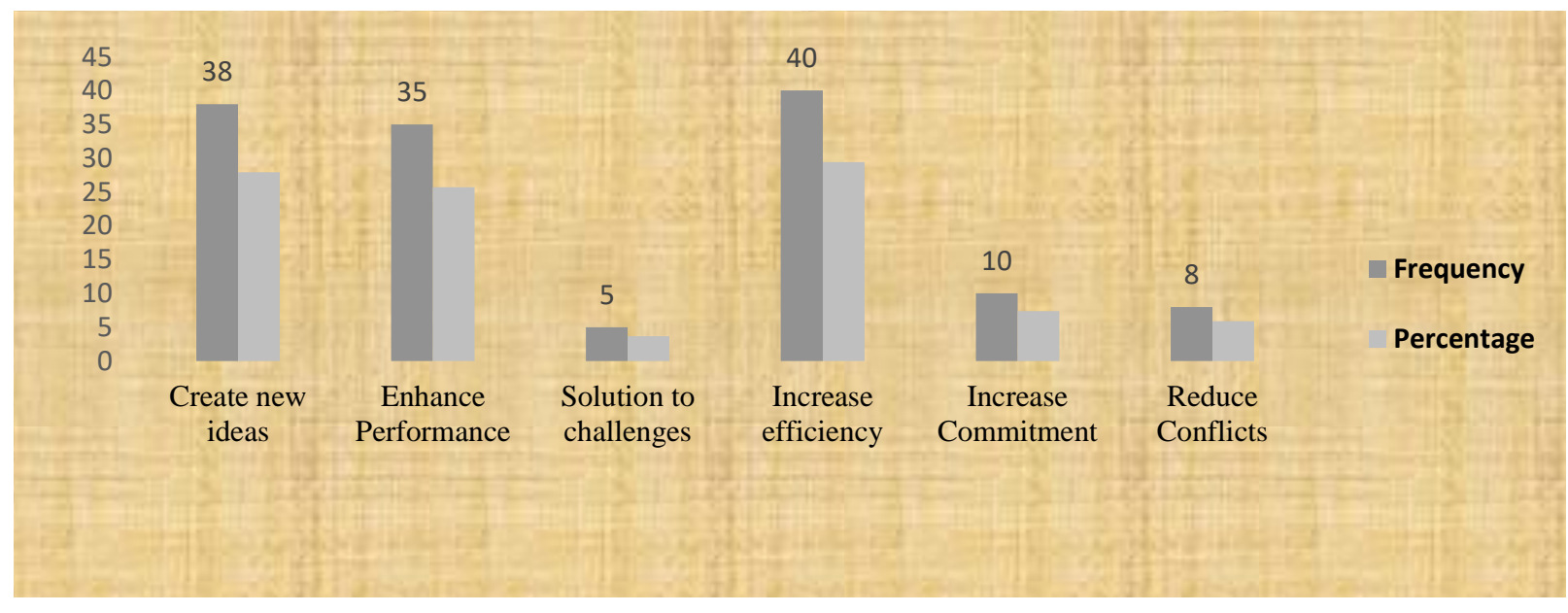

Fig.4.3 Importance of Teachers' Partaking in Decision Making

Source: Field data August 2021

The findings showed that participants had positive perceptions towards teachers' involvement in the decisionmaking process. They argued that involving teachers in decision-making led to new ideas, enhanced performance, increase efficiency, commitment, and reduced conflicts.

\section{Increase Efficiency}

Figure 4.3 demonstrated that 29.4 percent of teachers argued that involving teachers in decision-making helped to increase the efficiency of teachers in schools. Participants added that active involvement in decision-making motivated teachers and promote a sense of ownership and transparency to make an organization successful. Similarly, when interviewees were asked to explain the relationship 
between teacher participation in decision making and work performance an interviewee responded:

Involving teachers in decision-making helped teachers to gain experience increase their confidence in work, motivate teachers, and increase creativity and innovation which lead to school efficiency (Interviewee two, August 2021). In the same vein, another interviewee argued that Involving teachers in the decision-making process helped teachers to gain experience, felt motivated, and hence school vision and mission will be achieved easily (Interviewee Eight August 2021).

In addition, (Olurunsola and Olayemi in Nigeria, 2011) found that participation of teachers in decision making in the administrative activities helped teachers to gain experience, removes boredom, frustration and increases workers' commitment and efficiency. In the Meru district, there is evidence that heads of schools have good efforts to ensure teachers are involved in decision-making. In the observation, the data showed that in all five schools 100.0 percent had a vision and mission, timetable for staff meetings, and school objectives. Despite all valuable planning for involving teachers in the decision-making process, some teachers were unaware of the school vision and Mission. They were not able to state their school vision and mission. This situation resulted in ineffective performance in school. Moreover, in observation, the researcher recognized that all five public secondary schools (100.0 percent) had inadequate teaching and learning resources. Facilities such as books, classrooms, laboratories, and libraries were inadequate which drove back school efficiency.

\section{Creation of new Ideas}

The emergence of new ideas was also represented by participants as the importance of teacher involvement in decision-making. Figure 4.3 demonstrated 27.9 percent of the participants said concerning educators during the decision process that helps in the generation of new ideas in school. Participants said that enhancing teachers' participation in decision-making made teachers work in confidence, increase innovation and creativity. During the interview participants from WEOs said:

For the school to perform well, teachers should be fully involved in all school matters. Active participation in school management makes teachers motivated and to be active in innovation and creativity. This situation makes teachers give new ideas which are important for school survival (Interviewee Eleven, August 2021).

In the Meru district, the researcher discovered that for schools whose heads invested in the active participation of teachers, heads of departments were active and innovative. For example, through document analysis, it was found that 60 percent of schools were aware of the importance of the active contribution of educators in the decision. However, were encountered environmental challenges. In these schools, there was evidence of teachers' participation such as departmental minutes, files, meeting minutes, school calendar indicating time allocation for teacher's debates and framework which were vital for school success. Therefore, from the findings the researcher concluded that some teachers were very aware of the importance of involving teachers in decision making but, they are affected by environmental challenges such as inadequate facilities and insufficient funds. This led to the failure to implement the newly created ideas and hence lowered school performance.

\section{Enhances Students Performance}

The findings in figure 4.3 show that 25.7 percent of the participants revealed that involving teachers in decisionmaking enhances student academic performance in school. Participants argued that concerning educators in deciding process encourages a sense of accountability and commitment among teachers. From the interview, an interviewee said:

Teachers' involvement in decisionmaking helps teachers to be comfortable giving out their views and ideas to make programs effective in secondary schools. Teachers' input in a decision made them accountable and committed to program implementation. When teachers are accountable and committed to the planned school programs students' performance becomes higher (Interviewee nine, August 2021).

The findings were also supported by (Okuoko \& Dwumah, 2012) in Ghana who found that employee involvement in decision making impacted positively on workers' commitment and performance in the organization. Likewise, the conceptual framework in figure 1.1 indicated that Teachers' involvement in decision-making encourages accountability, commitment and improves students' academic performance in secondary schools. Also, Moradi and Shabbaz (2016) in discussing Transformational Leadership Theory maintained that transformational leaders employ their abilities to promote the ideas of others and transfer individuals to higher performance. Involving 
teachers in decision-making is vital to students' academic performance. In the Meru district, heads of schools do not involve teachers fully in the decision-making process. Heads of schools argued that there are challenges associated with ensuring the active involvement of teachers in the decision-making process. The challenges made schools perform not to the extent required. Therefore, there is a need to address school environmental challenges to enhance the best student academic performance in public secondary schools.

\section{Increases Teacher's Commitment}

The findings in figure 4.3 also pointed out that 7.4 percent said that teachers' involvement in the decision-making process increases their work commitment in school. Participants said that when they are involved in decisionmaking, they felt motivated and work voluntarily in their duties.

During the interview, an interviewee asserted that "Involvement in decision making made teachers to be active participants in school management and thus helped the leader to achieve school objectives (Interviewee Seven August 2021).

This implies that teachers' involvement in decision-making promotes teachers' commitment. Thus, school leaders must ensure teachers are involved in decision-making and leave behind their interest for school growth. Avolio (1999) in discussing Transformational Leadership Theory added that transformational leader transcends their interests for the growth of the organization. In the same vein, the conceptual framework showed that teachers' involvement in decisionmaking develops teachers' commitment and empowers their work performance in school.

In the Meru district, through observation, the data showed that the commitment of teachers to their work is 60 to 70 percent. The situation made schools have low performance. Teachers felt to be committed but inadequate facilities challenge their implementation and some school heads do not give adequate support hence decreasing teachers' commitment to work.

\section{Reduces School Conflicts}

Teachers' involvement in decision-making plays significantly in the learning setting. The finding indicated that 5.9 percent of the participants said that school conflicts may be reduced through the active participation of teachers in the decision-making process. In the interview participant said,

Conflicts in schools are the result of a lack of transparency and involvement. Teachers' participation in decisionmaking makes each teacher know what is going on in the school. They understand sources of income and amounts are given as well as expenditures. Everything becomes transparent and hence reduces many questions on financial frauds and embezzlement. Prolonged conflicts may be history for such a school (Interviewee six, August 2021).

In the Meru District council, teachers are well informed about finances received in school; hence transparency was not a problem. Heads of schools revealed that however teachers are involved in the financial decision; some teachers are stubborn and always quarreling with school administrators for their interest. This situation may lower their work performance in school.

\section{Solution to Challenges}

Some participants supported that teachers' involvement in making decision empower teachers to give out the solution to problems by 3.7 percent. In the interview, a participant asserted that:

Teachers' participation in decision-
making creates unity among teachers and
school administration. Teachers feel part
and parcel of the school management and
thus whatever challenges arise in the
school; the solution will be obtained
through collaborative discussions.
Therefore, participation is good to
improve teachers' work performance
(Interviewee One, August 2021).

The conceptual framework in figure 1.1 demonstrated that participation decision-making develops a sense of collaboration which is an essential element in problemsolving. There are challenges mentioned by participants as a block to teachers' participation in decision-making. The challenges such as inadequate funds and facilities can be solved if there were effective collaboration among teachers. For example, some schools can establish income-generating projects to support and cover some expenses. This can reduce dependence on central government financial disbursement only.

\section{Factors Affect Teacher's Participation in Decision Making}

In this objective, the researcher wanted to examine factors affecting teachers' participation in decision-making and work performance in public secondary schools in the Meru District council. Participants involved in the provision of data included teachers, heads of schools, Ward Education Officers, and DEO for secondary schools. Furthermore, the researcher used questionnaires to collate data from teachers. 
Heads of schools, WEOs, and District Education officers for secondary schools were interviewed. Also, a document checklist and observation checklist were employed to seek the realities of teachers' participation in decisions within their actual environment.
Participants were asked if there were challenges encountered in involving teachers in decision-making processes. The data showed that 89.0 percent replied "Yes" while 11.0 percent said "No" as indicated in figure 4.3

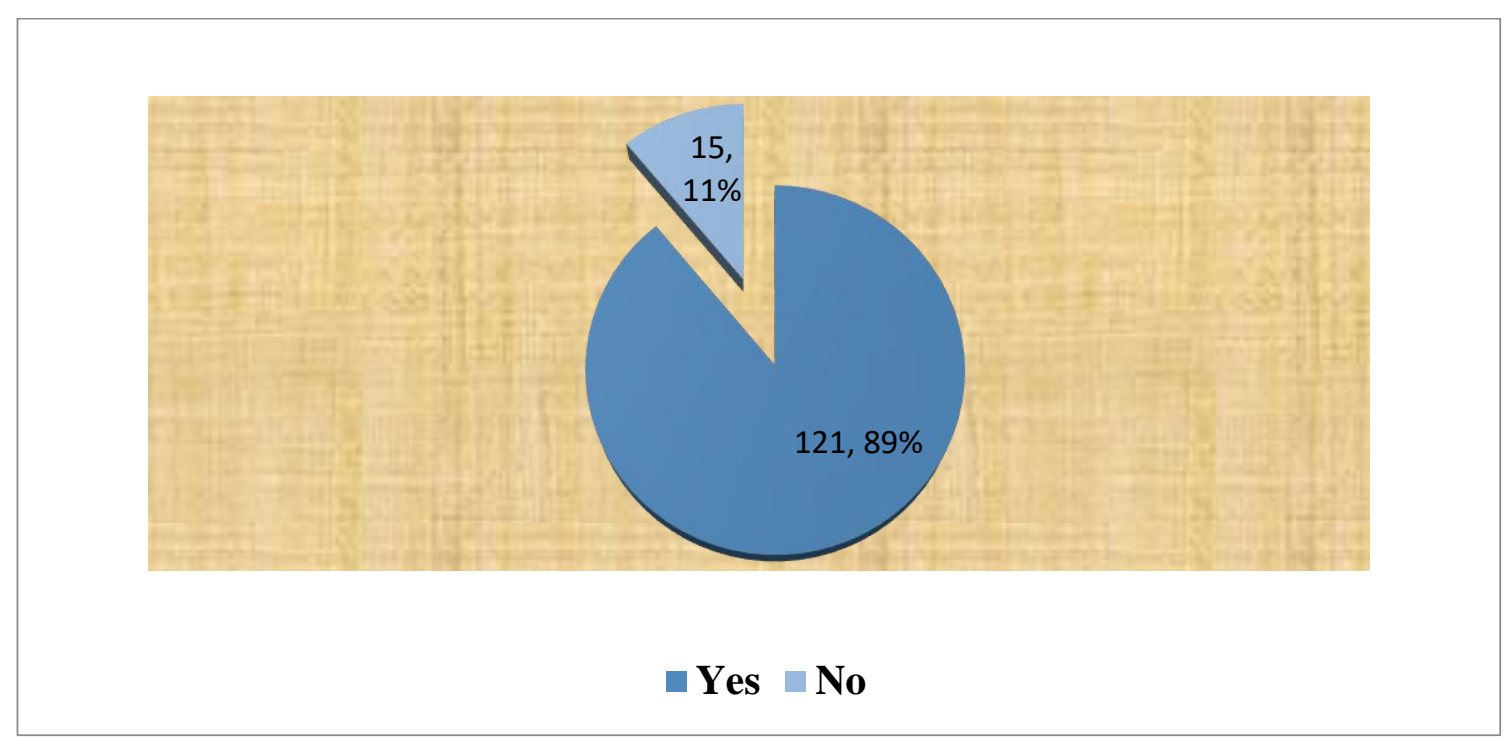

Fig 4.4 Teachers' Response on Factors Affecting Teachers in Decision-Making $(n=136)$

Source: Field Data August 2021

Figure 4.4 illustrates that the majority of the participants 89.0 percent understood that there are challenges to teachers' participation in the decision-making process.

The findings indicated that in Meru District teachers were involved in the decision-making process which is why they were able to recognize the challenges. Moreover, some participants 11.0 percent were not aware of teachers' participation in the decision-making process. The findings demonstrated that either they were new in the researched schools or neglected due to their negative perceptions.

Also, participants were asked to explain factors affecting teachers in the process of involving them in the decisionmaking process. The data showed they explain timeconsuming, lack of confidence among teachers, inadequate teaching and learning facilities, financial challenges, and leadership styles. Figure 4.5 represents the findings.

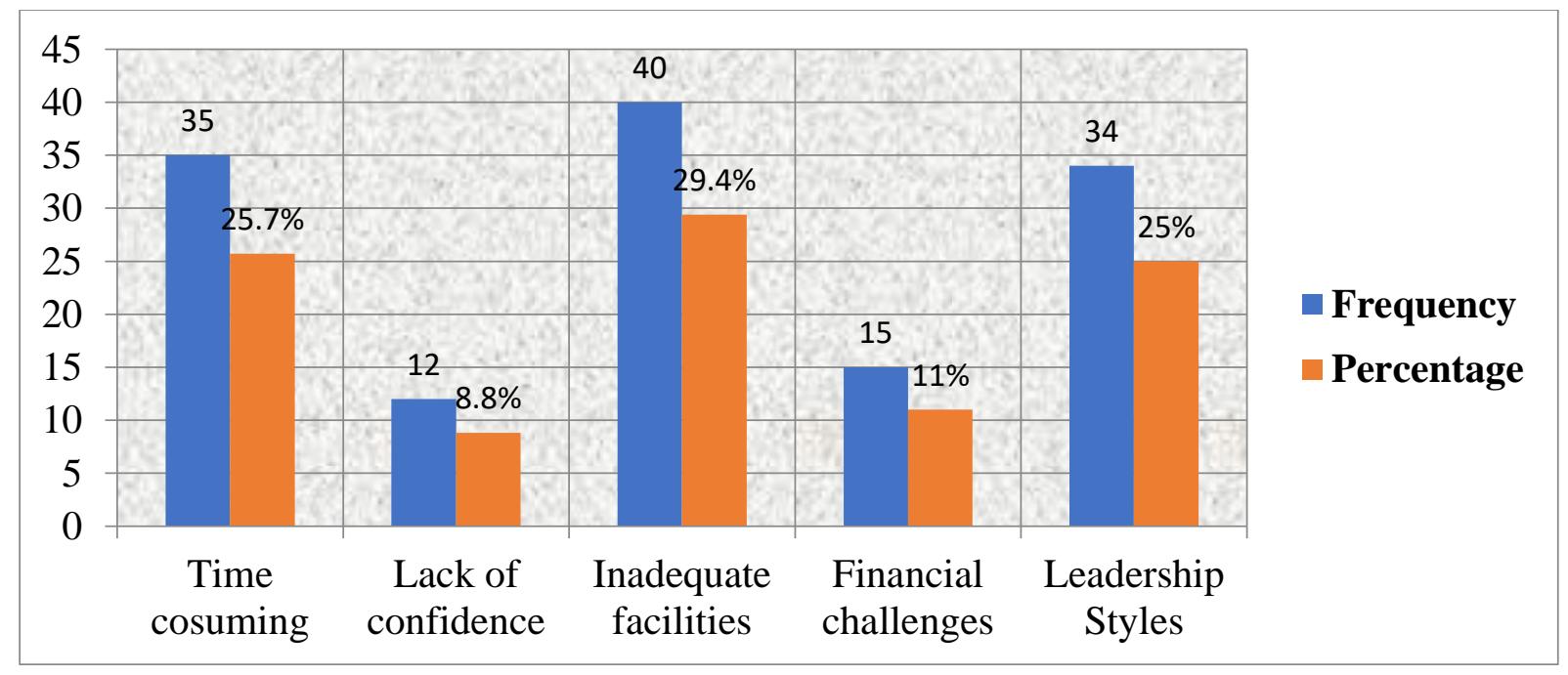

Fig.4.5: Factors Affecting Teachers Participation in Decision Making $n=136$

Source; Field Data, August 2021 


\section{Time Consuming}

The findings in figure 4.5 indicated that 25.5 percent of the participants said involving teachers in the decision-making process is the time consumed. Participants argued that teachers' participation in decision-making may consume a long time particularly if the decision is made by a large number of teachers. This entails that some teachers viewed participation in decision-making as insignificant to them and left the work of decision-making to principal administrators. The findings also concurred with (Hammad, 2017) in Egypt who found that teachers regarded school decisions as insignificant and irrelevant to their concerns. In Meru District, letting decision-making to principal administrators leads to low performance in public secondary schools. The conceptual framework showed that institutional challenges such as workers' and leaders' behavior may affect negatively teachers' participation in decision making and thus lower performance.

\section{Inadequate Facilities}

Notwithstanding, figure 4.5 pointed to inadequate facilities by 29.4 percent. The findings indicated that inadequate facilities such as books, classrooms, laboratories, and laboratory instruments are the major challenges that impacted to low performance in public secondary schools in Meru District. Through the document checklist, the data showed that 80.0 percent of schools investigated had no policy manual for teachers' participation however, 20.0 percent indicated that they were aware that policy manual was included in the education curriculum. Inadequate facilities demoralize teachers to participate fully in decision-making procedures. In the interview a participant maintained; "Inadequate participation of teachers in decision making, most of the time demoralizes teachers and hence loose morality in performing their duties" (Interviewee seven, August 2021). Just like others, another participant argued that teachers need / her opinion to be considered in the decision-making process. (Interviewee nine, August 2021).

The findings implied that inadequate facilities in public secondary schools made teachers not participate in the decision-making process by giving their ideas fearing failure to be implemented. The situation also made them have low working performance in schools. Moreover, Mugambi (2015) reported that inadequate teaching and learning materials, inadequate science laboratories, and libraries affected teachers' involvement in the decisionmaking process. Likewise, the conceptual framework in figure 1.1 showed that institutional challenges affect teachers' participation in decision-making. Not only a conceptual framework but also in transformational leadership theory maintained that visionary teachers channel their wants for the development of the institution through commitments and professionals' growth (Avolio, 1999). Thus, teachers feel motivated when their working environment is well equipped with adequate facilities to empower their work performance.

\section{Leadership Styles}

The findings in figure 4.5 showed that 25.0 percent said that type of leadership practiced in school affects educators' involvement in decision-making procedures. Participants showed that poor managerial skills among school heads impacted negatively decision-making. Also, in the conceptual framework, it is indicated that leadership styles and behaviors affect teachers' participation in decisionmaking and thus affect work performance. In the interview, a participant said that:

Some school heads are rigid and they
don't want to involve their teachers in
decision-making for all school matters.
They have their negative attitudes on the
effective participation of teachers.
Therefore, some of them apply a
dictatorship leadership style while others
believe in autocratic style for school
practices (Interviewee Ten, August
2021).

The finding entails that some school heads in the Meru district do not value the involvement of teachers in the decision-making process. The situation may affect the work performance of teachers and hence leads to low academic performance in students. The findings were contrary to the Transformational Leadership Theory which affirms transformational leaders are expected to facilitate change and encourage the development of personal potential among all members of or organization which makes organizational learning innovative (Chilin, Jiang \& Cheng, 2005).

\section{Financial challenges}

Figure 4.5 showed that 11.0 percent of the participants said that financial challenges affect teacher participation in decision-making. Participants entailed that some teachers secured their interest and whenever they called for participation debate, they wanted to be paid. Likewise, the interview participant said:

Of course, there is no fund allocated for motivating teachers during partaking in deciding during meetings. The amount of money disbursed in schools also is not adequate to supply adequate teaching and learning materials in schools. This condition does not motivate teachers in work performance (Interviewee Eleven, 
August 2021). Similarly, another interviewee noted that lack of funds for motivation made teachers' participation in decision-making challengeable (Interviewee Six, August 2021).

The finding implicates that inadequate financial disbursement in public secondary schools in Meru

District council hurts teacher participation in the decisionmaking process. The situation deteriorates teachers' work performance and affects students' academic success.

\section{Lack of confidence}

Also, figure 4.5 showed that 8.8 percent said school heads lack the confidence to involve teachers in decision-making and empower work performance. Participants asserted that some heads of schools cannot influence teachers and get them involved in decision-making. An interviewee asserted that:

The use of dictatorship style and personal incapability to include educators in every aspect of decision-making prohibits the creation of new ideas in school and hence lowers teachers' work performance (Interviewee Nine, August 2021).
The findings demonstrated that some school heads in the Meru district do not engage their teachers in decisionmaking in all aspects. This is caused by either lack of leadership skills or personal interest. The situation lowers work performance in teachers as well as students' academic achievement in public secondary schools.

In the interview, participants were asked to give the challenges on teachers' participation in decision-making on empowering teachers in work performance in public secondary schools in Meru District. They explain corruption and bribe, selfishness, misunderstanding among teachers, poor management and leadership, disunity, and classes in leadership.

\section{Barriers to Teachers' Participation in Provision of Ideas}

Participants were asked to explain barriers that prohibit teachers to provide their ideas for the decision-making process. The researcher was interested to find out if teachers are involved in the decision-making process to give their ideas. The respondents asserted that corruption, selfishness, misunderstanding, disunity, and classes were the barriers for the teachers to give their ideas during the decisionmaking process as indicated in figure 4.6

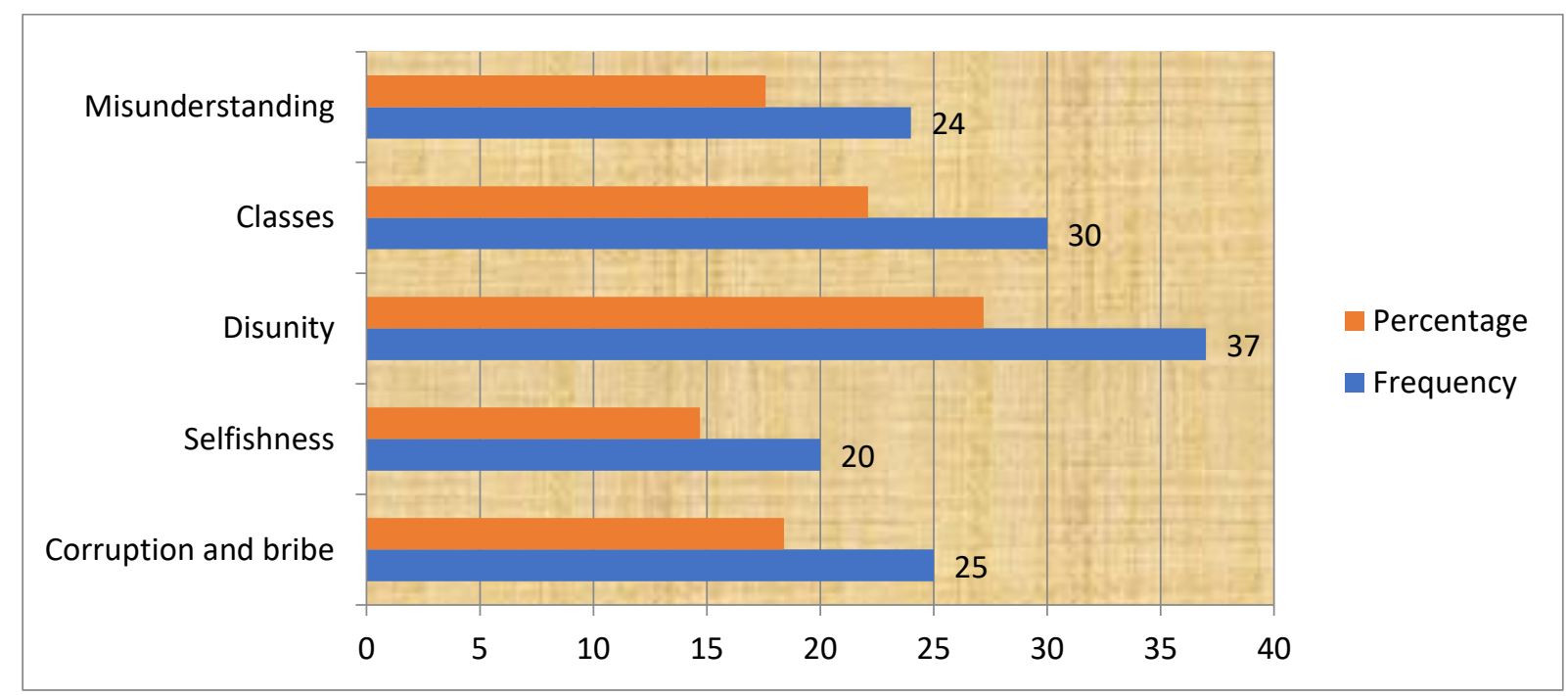

Fig.4.6 Teachers barriers in the provision of ideas $(n=136)$

Source: Field Data August 2021

\section{Disunity among Teacher}

In seeking for the barriers that hinder teachers from giving ideas in the process of decision making, Figure 4.6 showed that 27.2 percent argued on disunity. Participants maintained that a lack of unity among teachers in school made some teachers not give their ideas in the decisionmaking process. During the interview, an interviewee from school asserted that:
Sometimes you may call a staff meeting to seek ideas from teachers on a certain issue, but you may find some teachers do not air out their ideas. Generally, you cannot force a teacher to give their ideas because participation in the meeting is something voluntary. To involve is one 
thing but participation is also another issue (Interviewee 5 September 2021)

The findings implied that some teachers in the selected schools in the Meru District council might have either their interest or fear to give their ideas in the decision-making process. The finding also showed that there was no strong unity among teachers that affected the decision-making process. The findings are in line with (Meintjes, 2018) who revealed that the absence of confident teachers, dialogical teachers' voices in staffrooms and staff meetings, and lack of collegiality in staff relationships affected teachers' participation in decisions in schools. Thus, it is crucial to strengthen teachers' unity and confidence to participate in different matters.

\section{Classes among Teachers}

In the same vein, figure 4.6 indicated that 22.1 percent asserted that classes among teachers affect decision-making power in public secondary schools. Participants argued that classes arise where there is the favor for some teachers while others are not favored. The findings entailed that in the selected schools in Meru, some teachers were favored while others were not. The situation may lead to the emergence of classes among teachers which affects decision-making power. The findings were contrary to Transformational Leadership Theory as affirmed by (Chinlin, Jian \& Cheng, 2004) that transformational leaders are expected to facilitate change and encourage the development of personal potential among all members of their organization. They also make organizational learning and innovation possible. Similarly, (Jovanovic \& Ciric, 2016) maintained that teachers' involvement in making decisions cannot be separated from transformational leadership in the school setting. Therefore, transformational leadership theory required leaders to treat subordinates equally to harvest their potential.

\section{Corruptions}

Figure 4.6 demonstrated that 18.4 percent reported that bribes and corruption were barriers to teachers in giving out their ideas. The finding implied that in the selected schools there were elements of corruption and bribes. This means that the ideas of some teachers were accepted easily by school administrators compared to the others. This situation affected the participation of teachers in the decision-making process. The findings were in line with (Mndeme, 2014) who noted that poor management and planning system, corruption and delay in information and documents to reach the targeted persons, lack of teacher's participation in decision making on different matters affect the performance of teachers. Thus, heads of schools should abolish all kinds of favor for some teachers and treat all teachers equally regardless of their status.

\section{Misunderstanding among Teachers}

From the findings, the researcher found that misunderstanding among teachers in public secondary schools affects teachers to give their ideas in decision making. Figure 4.6 indicated that 17.6 percent argued that misunderstanding leads to poor participation in decisionmaking. The finding implied that there was a misunderstanding among teachers in the selected schools. It was found that misunderstanding among teachers creates classes in which some teachers got favor from school administrators. The situation creates misunderstanding among favored teachers and unflavored one and later one group neglects to give their ideas in the decision-making process. The conceptual framework showed that institutional challenges may affect the decision-making process resulting in poor work performance in public secondary schools. Furthermore, (Kiumi, Chemnjor, and Macharia, 2014) identified that autocratic leadership behavior nature an exclusive decision-making pattern, and principals do not have human relation skills and consensusbuilding skills in the decision-making facet of school management. The misunderstanding is caused by principals who do not have the human relations skills to settle all school disputes.

\section{Selfishness among Teachers}

Figure 4.6 showed that 14.7 percent argued that selfishness prohibits some teachers to give out their ideas in the decision-making on behalf of the school. The findings entailed that some teachers were selfish. They wanted their ideas to be implemented first than the ideas of others. This condition prohibits some teachers not to giving out their ideas because they are afraid of being unimplemented. Therefore, in the selected schools, there was a need to develop school culture. This could give room to respect the ideas of each participant in the decision-making process.

\section{CONCLUSIONS}

The study examined the relationship between teacher participation in decision-making on job performance. Based on the findings, the researcher concluded that there is a strong relationship between teachers' participation in decision-making and their work performance. Participation of teachers in decision making increases their efficiency, develops new ideas as well as increases commitment and accountability in performing their activities in school. Thus, school administrators have to find the right way to involve teachers in decision-making to improve their work performance and achieve higher performance.

Moreover, the study found that financial deficits, leadership styles, lack of training for school leadership, inadequate 
time for involvement, and lack of confidence among school administrators were the major factors affecting teachers' participation in decision-making in schools. Therefore, there should be efforts to deal with the challenges to empower teachers in decision-making to improve their work performance.

\section{RECOMMENDATIONS}

Teachers' involvement in decision-making is vital to school success. This study sought to examine the relationship between teachers' participation in decision making and work performance and factors hindering teachers' attention in decision making. The researcher proposed that based on the idea of decentralization and concentration of all stakeholders of education; the Ministry of Education Science Technology and Higher Education should develop a clear policy guideline to ensure teachers are included in the decision-making process. The policy should focus on eliminating all barriers to the success of education. in Tanzania.

Also, heads of schools should work collaboratively with teachers and the community to eliminate all barriers to promote their effective participation in decision-making. For example, provision of a facilitative environment that motivates teachers. It works efficiently through the provision of adequate facilities for teaching and learning. Likewise, improve working conditions and payment to teachers.

\section{REFERENCES}

[1] Atseba, A. T. (2016). Principal s leadership styles and the effects on teacher's performance in the Tigray Region of Ethiopia [Unpublished Doctoral Thesis, University of South Africa].

[2] Creswell, J. W. (2012). Educational Research: Planning, Conducting and Evaluating Quantitative and Qualitative Research (4th ed.). Boston: Pearson Education, Inc.

[3] Eris, H., Kayhan, H., Bastas, M. and Gamar, C. (2017). Teacher and administrative staff views teachers' participation in the decision process. Eurasian Journal of Mathematics Science and Technology Education, 13(11), 7411-7420. doi.10.12973/ejmse/79794

[4] Godda, H.G. (2014). Decentralization of secondary school's management in Tanzania: Strength and prospects St. John University of Tanzania Dodoma. Journal of Education and Practice, 5(37)

[5] Hammad, W. (2017). Decision domains and teacher participation. A qualitative investigation of decision making in Egyptian schools. The qualitative report. International Journal of Modern Education Research, 22 (9), 2478-2493.

[6] Haradhan, M. (2017) Two criteria for good measurements in research: Validity and reliability. Journal of Munich Personal Repec Archive
[7] Haryanto, S. (2020). Teachers' involvement in decision making and job performance in secondary schools contents in Kwara Nigeria. Journal Pendikan SainSosial Dan Kemamasiaan 1-12.

[8] Kariuki, J. K. (2018). Principals' transformational leadership and teachers' performance among Public schools in Nyandarua county Kenya [Unpublished Master Dissertation, The Catholic University of Eastern Africa, Kisumu, Kenya].

[9] Kiumi, J. K., Chemnjor, C. M. \&Macharia, M. K. (2014). Determinants of teacher involvement in the decision-making process by secondary school principals in Nyahururu sub count Kenya. International Journal of Modern Education Research, 1(3), 53-60.

[10] Meintjes, S. N. (2018). Participatory decision-making in schools. A study of two schools in Gauteng [Unpublished Master Dissertation, University of Jonesburg, Jonesburg, South Africa]

[11] Mohammed, M. H. (2017). Teachers' involvement in decision making in government secondary schools of Gulelesubcity in Addis Ababa Ethiopia [Master Dissertation, Addis Ababa University, Addis Ababa, Ethiopia]. https://nsu works/nowa.ed/lgr/ 22. 9-14

[12] Mugambi, M. D. (2015). The role of principals in promoting students' academic performance in Tigania West Sub-county Meru County Kenya [Unpublished Master Dissertation Kenyatta University, Nairobi, Kenya].

[13] Mndeme, A. (2014). The management of teachers' motivation in Tanzania's education sector. The case of public secondary schools in Temeke municipality Tanzania [Unpublished Master Dissertation University of Dar es Salaam, Dar es Salaam, Tanzania].

[14] Mbope, N. A. (2015). The impact of teachers' motivation on the improvement of the quality of teaching and learning in public primary school in Ilala [Unpublished Master Dissertation, The Open University of Tanzania, Dar es Salaam, Tanzania].

[15] Ngussa, B. M., \& Gabriel, L. (2017). Participation in decision making and teachers' commitment A comparative study between public and private secondary school in Arusha, Tanzania. American Journal of Education Research, 5(7), 801-807. DOI: 10.12691/education-5-7-17.

[16] Owusu, A. A., \& Yiboe, T. (2014). Participation in professional programs and curriculum implementation: Perspective of senior high school French teachers in Ghana. Journal of Education and Practice, 5(8), 98-112. https://www.researchgate.net/publication/264232348.

[17] Ozan,B., Ozdemir, Y.T., and Yirci, R.(2017). Ethical leadership behaviors of school administrators from teachers' point of view. Foro de Education, 15(23), 161184.doi.http//dx. doi.org /10.14516.

[18] Olorunsula, E. O and Olayemi, A.O. (2011). Teachers' participation in the Decision-making process in secondary schools in Ekiti State, Nigeria. Journal of Education Administration and policy studies, 3(6), 78-84

[19] Paulsrud, D. and Wermke, w. (2020). Decision making in context Swedish and Finnish teachers' perceptions of 
autonomy. Scandinavian Journal of Educational Research, 64(5), 706-727. doi.10.1080/0031.2019.1596975

[20] Sagvandy, R. S., \& Omidian, F. (2015). Teachers' participation in different levels of decision-making in council and developing professional skills in Iran. World Scientific News, 9(2015), 17-27.

[21] Surkino, D. S. and Siengthai, S. (2011). Does participative decision-making affect lecturer performance in higher education? International Journal of Educational Management, 25(5), 494-508. doi.101108 09513541111146387

[22] Tchapchet, E.T., Iwu, C. G. and Ile, C. A. (2014). Employee participation and productivity in South Africa. University implications for human resource management. Journal Problems and Perspectives in Management, 12(4), 293-304

[23] URT. (2010). Secondary education development program II (2010-1015). Ministry of Education and Vocation training.

[24] URT. (2013). Education sector development plan (20132017). Ministry of Education.

[25] URT. (2017). Education sector development plan (2016/172020/21). Ministry of Education, Science, and Technology

[26] Wadesango, N. (2012). The influence of teacher participation in decision making on their occupational morale Zimbabwe. Journal of social science, 31 (3) 361-369 